\title{
THE PRENATAL DEVELOPMENT OF THE BUFFALO OVARY
}

\author{
F. EL-GHANNAM AND M. A. EL-NAGGAR \\ Department of Obstetrics and Gynaecology, Faculty of Veterinary Medicine, \\ Assiut University, Assiut, Egypt
}

(Received 30th May 1974)

The development of the fetal ovary has been studied in cattle (Hashimoto \& Eguchi, 1955; Sakai, 1955; Henricson \& Rajakoski, 1966), pigs (Black \& Erickson, 1968), rats (Beaumont \& Mandl, 1962) and man (Baker, 1963).

In cattle, the ovaries remain attached to the mesonephros until the fetus reaches a crown-rump length of $11 \mathrm{~cm}$, and the descent is completed when the crown-rump measurement is $21.5 \mathrm{~cm}$ (Sakai, 1955). The weight of the ovary steadily increases, coincident with the increase in the number of germ cells, from the 50th day post coitum (Sakai, 1955; Erickson, 1966), and there is a sharp increase in the 9th month of pregnancy (Erickson, 1966). The volume of the fetal ovary increases linearly (Sakai, 1955). According to Sakai (1955), sex differentiation of the fetal ovary of the cow occurred as early as the 30th day of gestation, and the maximum number of oocytes was reached when the crown-rump length was $40.5 \mathrm{~cm}$ (110th day of gestation); thereafter, oocyte numbers decreased suddenly (Erickson, 1966). Primary follicles were formed at a crown-rump length of $15 \mathrm{~cm}$ but their numbers decreased later in pregnancy (Sakai, 1955; Hashimoto \& Eguchi, 1955).

The only information on the prenatal development of the buffalo ovary is that by Ghannam \& Deeb $(1967,1969)$, who stated that differentiation of the gonadal primordia occurred at a crown-rump length of $7 \mathrm{~mm}$, sex differentiation was at $20 \mathrm{~mm}$, and primordial follicles were first observed at $600 \mathrm{~mm}$, continuing to develop until birth.

The present study of the ovary of the fetal buffalo was undertaken to increase knowledge of this species, an important livestock animal in Egypt.

The ovaries of forty-three buffalo fetuses were dissected, weighed and measured, fixed in $10 \%$ formalin, dehydrated and embedded in paraffin wax. Sections were cut at $6 \mu \mathrm{m}$ and were stained with haematoxylin and eosin or by the Azan or periodic acid-Schiff techniques. The age of the fetus was estimated from measurement of the crown-rump length along the vertebral curvature according to the method of Abdel-Raouf \& El Naggar (1968).

The germinal cell population was assessed by the technique of Dornfeld, Slater \& Schéffe (1942) which gives an approximate number of germinal cells/ $\mathrm{mm}^{3}$ ovarian tissue. Five of the largest sections of ovary (from the centre of the wax block) were projected onto paper at a magnification $(m)$ of $\times 100$ and their total surface area (S) was determined using a planimeter. The volume 
$\left(V_{0}\right)$ of the portion of the ovary so examined was estimated (in $\mathrm{mm}^{3}$ ) using the formula (modified from Dornfeld et al., 1942): $\mathrm{V}_{\mathrm{O}}=\mathrm{S} \times \mathrm{t} / \mathrm{m}$, where $\mathrm{t}=$ section thickness. The volume of the germinal cells $\left(V_{0}\right)$ was calculated from the formula: $V_{c}=1.3 \times \pi r^{3}$, where $r=$ radius of the cell. This formula was applied to 100 germinal cells in each of the five sections examined from each ovary. The cells were measured using an eyepiece micrometer calibrated to the nearest $0.1 \mu \mathrm{m}$ and were assumed to be spherical. The average number of germinal cells $(P)$ in each of the five sections examined from each ovary was obtained using the formula of Abercrombie (1946): $P=t /(t \times 2 r) \times$ number of cells measured.

Thus, the total population of germinal cells $/ \mathrm{mm}^{3}$ ovarian tissue was derived from the formula: $\mathrm{N}=\mathrm{P} / \mathrm{V}_{\mathrm{O}}$.

The 100 germinal cells counted in one section of each ovary were assessed as normal or degenerating (Beaumont \& Mandl, 1962; Black \& Erickson, 1968). The degenerating forms were classed as (i) pyknotic oogonia, and (ii) degenerating oocytes in the pachytene stage forming the ' $\mathrm{Z}$ cells'.

At a gestational age of 3 months, the ovaries appeared as oval or spindleshaped symmetrical thickenings just cranial to the anterior end of the differentiaing Müllerian ducts and attached to the caudo-lateral borders of the kidneys. The final pelvic position of the ovaries was reached by the end of the 6 th month and the right ovary was slower to descend than the left.

Ovarian weights at different fetal stages are shown in Table 1. No significant differences were found between the weights of the right and left ovaries but there was a significant correlation $(r=0.694)$ between the weight of the ovaries and the crown-rump length.

At the 3rd month of gestation, the gonads were at a late stage of differentiation: the tunica albuginea was poorly differentiated but primitive germinal, granulosa, thecal and stromal cells were present. The germinal cells were mostly oogonia, many of which were in mitosis but some pyknosis was observed. A few oocytes were in early meiosis. By the 4th month, the germinal epithelium was invading the gonad to form epithelial cords and the rete ovarii were apparent. The germinal cells were still at the oogonial stage and many, particularly those in the centre of the organ, were degenerating. During the 5th month, the ovarian stroma and the tunica albuginea became more organized and sex cords were seen invading the stroma. Meiotic activity was apparent and formation of primordial follicles began. Many oogonia were degenerating. The formation of primordial follicles was still the characteristic feature in the ovaries of 6-month-old fetuses. Organization of the follicles was better at the cortex of the ovary than in the centre where more oocytes showed degenerative changes, and the stromal cells were abundant, forming 'whirls'. During the 7th and 8th months, the tunica albuginea reached its maximum thickness $(200 \mu \mathrm{m})$ and the cells of the germinal epithelium became flattened. There were few oogonia, most of the germinal cells being oocytes. Several oocytes were undergoing degeneration to form ' $Z$ cells' (Beaumont \& Mandl, 1962). At the 9th and 10th months, hormonal activity was indicated by the formation of vesicular follicles which became atretic. The ovary was more clearly divided into cortical and medullary zones and germinal cells were found only in the former. 


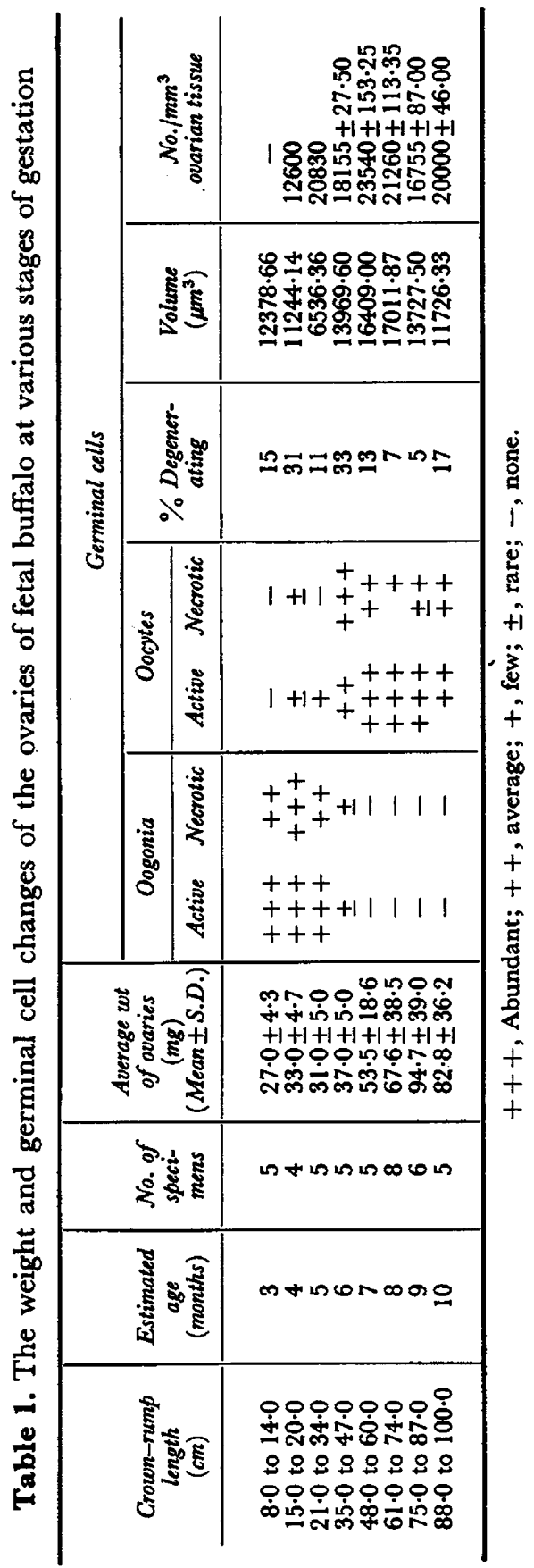


The germinal cells, identified by their nuclear configuration, reached their maximum volume at the 8th month of gestation (Table 1). Peak degeneration of oocytes at pachytene also occurred at this time. The total number of germinal cells increased progressively until birth but the number $/ \mathrm{mm}^{3}$ ovarian tissue did not appear to alter greatly during gestation (Table 1).

The sudden increase in weight of ovaries from the 8th to the 10th month of gestation coincided with the development of atretic vesicular follicles and with the increase in maternal plasma FSH levels at that time (Abdo, 1962). Similar findings have been recorded by Ghannam \& Deeb $(1967,1969)$ for buffalo and by Erickson (1966) for cattle.

The four ovarian cell types distinguished in the fetal ovary of the buffalo by their morphological and tinctorial properties were primordial germinal cells, granulosa cells, thecal cells and stromal cells (Gillman, 1948; Brambell, 1956; Ohno, Kaplan \& Kinosita, 1958; Wells, 1959; Ohno \& Smith, 1964; Black \& Erickson, 1968).

None of the fetuses used in the present study was young enough to have gonads in the indifferent stage and although there was a wide range of crown-rump measurements in the 3-and 4-month-old fetuses, all of the gonads contained the four ovarian cell types and were demonstrably ovaries. The growth phase was apparent from the 4th month and was indicated by the distinction between the cortex and medulla. Late in the 5th month and early in the 6th month, ovarian organization was characterized by the development of follicles, particularly in the cortex.

Oogonia were positively identified in the 3rd and 4th month of gestation. By the 6th month, their numbers had decreased and few were visible. The increased degeneration to which this can be attributed is believed to be due to invasion of the centre of the ovary by the stromal cells (Gillman, 1948). Baker (1963), however, has observed oogonia throughout the intrauterine life of the human fetus. This variation in the time of disappearance of oogonia may be due to differences in gestation length, specific differences, or both. The suggestion of Gillman (1948) that germinal cells enclosed by granulosa cells are more likely to survive may explain the rapid disappearance of the naked germinal cells in the later stages of development.

Oocytes appeared sporadically as early as the 3rd month and progressively increased until birth. The number $/ \mathrm{mm}^{3}$ ovarian tissue remained fairly constant from the 5th month except during the 9 th month. The enclosure of oocytes by granulosa cells to form the primordial follicle coincided with the first stages of meiotic prophase. The finding that the number of germinal cells $/ \mathrm{mm}^{3}$ ovarian tissue was highest in the 7th month of gestation confirmed that of Ghannam \& Deeb (1969) for this species. A similar pattern has been found in man (Baker, 1963) and cattle (Sakai, 1955; Erickson, 1966).

There were three waves of degeneration of the germinal cells. The first affected the oogonia and was at a maximum in the 4 th month. The second and third waves affected oocytes and occurred at the 6th month and near term, respectively. Similar waves have been reported by Baker (1963) for man.

The authors are greatly indebted to Professor Dr M. Abdel-Raouf, head of 
the Department of Obstetrics and Gynaecology, Faculty of Veterinary Medicine, Assiut University, for his help and advice.

\section{REFERENCES}

AbdeL-Raouf, M. \& Er Naggar, M. A. (1968) Biometry of the Egyptian buffalo foetus. UAR 7. vet. Sci. 5, 37.

ABDo, M. S. (1962) Hormonal variations in the blood of buffaloes during pregnancy. 7 . Egypt. vet. Med. Ass. 9, 37.

Abercrombie, M. (1946) Cited by Green, S. H. \& Zuckerman, S. (1961) The number of oocytes in the mature Rhesus monkey, Macaca mulatta. F. Endocr. 7, 194.

BAKER, T. G. (1963) A quantitative and cytological study of germ cells in human ovaries. Proc. R. Soc. $B, 158,417$.

BEAUMONT, H. M. \& MANDL, A. M. (1962) A quantitative and cytological study of oogonia and oocytes in foetal and neonatal rat. Proc. $R$. Soc. B, 155, 557.

Black, J. L. \& ERICKson, B. H. (1968) Oogenesis and ovarian development in the prenatal pig. Anat. Rec. 161, 45.

Brambell, F. W. R. (1956) Ovarian changes. In Marshall's Physiology of Reproduction, 3rd edn, Vol. I, pt. I, p. 397. Ed. A. S. Parkes. Longmans Green, London.

Dornfeld, E. J., Slater, D. W. \& Scheffe, H. (1942) A method of accurate determination of volume and cell numbers in small organs. Anat. Rec. 42, 255.

ERICkson, B. H. (1966) Development and radio-response of the prenatal bovine ovary. 7. Reprod. Fert. $11,97$.

Ghannam, S. \& Deeb, S. (1967) Prenatal development of some endocrine glands in buffaloes. UAR F. vet. Sci. 4, 63.

Ghannam, S. \& Deeb, S. (1969) Prenatal development and activity of the ovaries in buffaloes. UAR 7. vet. Sci. 6, 105.

GiLLMAN, J. (1948) The development of gonads in man, with a consideration of the role of the foetal endocrines and histogenesis of ovarian tumors. Contr. Embryol. 32, 81.

Hashimoto, Y. \& EGUChi, Y. (1955) Histological observations on the gonads in the cattle and the horse foetus. 1. The cattle foetus. Fap. F. zootech. Sci. 26, 259.

Henricson, B. \& Rajakoski, E. (1959) Studies of cytogenesis in cattle. Cornell Vet. 49, 494.

Ohno, S., Kaplan, W. D. \& Kinosita, R. (1960) Isopycnotic behaviour of the bivalent oocytes of Rattus norvegicus. Expl Cell Res. 19, 637.

OhNo, S. \& Sмiтh, J. B. (1964) Role of foetal follicular cells in meiosis of mammalian oocytes. Cytogenetics, 3, 324.

SAKAI, T. (1955) Studies on the development of the embryonic ovary in swine, cattle and horse. $\mathcal{F} a p . \mathcal{F}$. vet. Res. 3,

WeLLS, L. (1959) Anatomy of the female reproductive organs. In Reproduction in Domestic Animals, p. 119. Eds. H. H. Cole and P. T. Cupps. Academic Press, New York and London. 